\title{
Adult Human Keratinocytes Migrating over Nonviable Dermal Collagen Produce Collagenolytic Enzymes That Degrade Type I and Type IV Collagen
}

\author{
David T. Woodley, M.D., Tea Kalebec, M.D., Albert J. Banes, Ph.D., William Link, Ph.D., \\ Michel Prunieras, M.D., and Lance Liotta, M.D. \\ Departments of Dermatology (DTW) and Surgery (AJB, WL), University of North Carolina School of Medicine, Chapel Hill, \\ North Carolina, and Laboratory of Pathology (TK, LL), National Institutes of Health, Bethesda, Maryland, U.S.A., and \\ Department of Cell Biology (MP), Center for International Dermatologic Research, Valbonne, France
}

Human adult keratinocytes migrating on a nonviable dermal substrate in cultures without fibroblasts induce thinning and degradation of the collagen substrate beneath the migrating epithelium. Further, unconcentrated conditioned medium from the cultures exhibit collagenolytic activity against both type I and type IV collagen which is inhibited by EDTA but not by phenylmethylsulfonyl fluoride or $\mathrm{N}$-ethylmaleimide. Since the migrating epithelium and dermal substrate do not contain fibroblasts, this study shows that migratory keratinocytes in contact with interstitial collagen are capable of producing collagenases against type I and type IV collagen. Moreover, migratory keratinocytes appear to be similar to highly metastatic cells in their ability to degrade basement membrane collagen. J Invest Dermatol 86:418-423, 1986

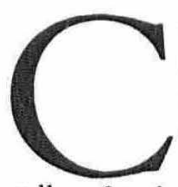

ollagenases are metalloproteinases capable of degrading collagen, a major class of connective tissue molecules. Collagens show a relative resistance to degradation by other types of proteinases. Collagenase enzymes were first detected in the epithelial cells of tadpoles [1]. In human skin, however, the majority of the collagenase enzyme which degrades interstitial collagens (types I, II, and III) is localized to the papillary dermis and is synthesized by dermal fibroblasts [2-4]. Nevertheless, in 1979, Eisen [2,3] also detected small amounts of human skin collagenase in normal human epidermis and much greater amounts in the epidermis of wounded skin and in the epidermis of patients with epidermolysis bullosa dystrophica. In these patients, the epidermal-derived collagenase exceeded that found in the papillary dermis [3].

In accordance with the human skin studies of Eisen [2,3], Grillo and Gross [5] and Donoff and coworkers [6,7] detected interstitial collagenases in cultures of epithelial cells obtained from the leading edge of epithelium covering the granulation tissue bed of wounded rodent skin. These studies and those of Eisen [2,3] show that epidermal cells from both human and rabbit skin are capable of producing a collagenase that degrades interstitial collagens under certain conditions.

Manuscript received March 18, 1985; accepted for publication October 24,1985 .

Supported in part by a Dermatology Foundation grant, IN-15Y from the American Cancer Society, and R01 AM33625 from the National Institutes of Health.

Reprint requests to: David T. Woodley, M.D., The University of North Carolina at Chapel Hill, Room 137, North Carolina Memorial Hospital, Chapel Hill, North Carolina 27514.

Abbreviations:

NEM: N-ethylmaleimide

PMSF: phenylmethylsulfonyl fluoride
In contrast to the interstitial collagens, the major collagen found in basement membranes, type IV collagen, is not degraded by human skin collagenase derived from dermal fibroblasts $[4,8,9]$ or other similar collagenases that degrade interstitial collagens $[10,11]$. Type IV collagen has unique biochemical properties that distinguish it from other collagens such as a high carbohydrate content and nonhelical domains within the molecule [12,13].

In contrast to human skin collagenase, collagenase derived from highly metastatic cell lines such as a murine melanoma $[14,15]$ specifically degrades only type IV collagen while leaving interstitial collagens intact. This type IV collagen-specific enzyme is found also in inflammatory cells, but is not produced by a variety of normal cell lines including mouse and human fibroblasts $[14,15]$.

Except for the 2 papers by Eisen $[2,3]$, to our knowledge, there have been no published studies of human keratinocyte-derived collagenases. We have been using the human keratinocyte culture technique of Freeman et al [16] and Milo et al [17] to study differentiation, reconstitution of the cutancous basement membrane, and as an in vitro model of wound healing [18-21]. In this culture system, human keratinocytes migrate across nonviable pig dermis. The dermal substrate is kept at an air-fluid interface which allows the keratinocytes to proliferate while preventing fibroblast growth $[16,17,19,21]$. The keratinocytes are in intimate contact with interstitial collagens and are in a highly migratory state similar to that during wound healing. The migrating keratinocytes reconstitute part of the basement membrane zone (the bullous pemphigoid antigen) [18] but do not exhibit type IV collagen or a continuous ultrastructural lamina densa at the cell-substrate interface [20]. One notable feature of these cultures is that the substrate beneath the cultured cells appears thin and degraded. The purpose of this study was to examine the possibility that these human keratinocyte cultures were producing soluble enzymes capable of degrading collagen. Collagenase activity might explain the observed thinning of the substrate and the lack of type IV collagen in the reconstituted basement membrane zone of the cell-substrate junction [20]. 


\section{MATERIALS AND METHODS}

Cultures The keratinocyte culture technique of Freeman and coworkers [16] was used with slight modifications [18]. The cultures were continued for 40-55 days and maintained in Eagles' minimal essential medium with $20 \mathrm{~mm}$ HEPES buffer supplemented with $0.1 \mathrm{~mm}$ nonessential amino acids, $1 \mathrm{~mm}$ sodium pyruvate, $2 \mathrm{~mm}$ glutamine, $100 \mu \mathrm{g} / \mathrm{ml}$ streptomycin, $100 \mathrm{U} / \mathrm{ml}$ penicillin, and $10 \%$ fetal calf scrum. Adult normal human skin obtained from surgical specimens was used in all cultures. The skin was cut into thin sheets with a Castroviejo keratome set at a depth of $0.3 \mathrm{~mm}$. The sheets were cut into $0.5-1.0 \mathrm{~mm} \times$ $0.5-1.0 \mathrm{~mm}$ square pieces with a scalpel and placed on a $4.0 \times$ $4.0 \mathrm{~cm}$ piece of killed, irradiated, inverted pigskin (Genetic Laboratories, Minneapolis, Minnesota) at an air-fluid interface which inhibits fibroblast growth and allows the epidermal cells to migrate away from the explants across the substrate and eventually cover it [16-21]. The medium and bacteriologic Petri dishes were changed twice a week by using a sterile forceps to lift the grids with the cultures out of the old dishes and place them into new dishes with fresh medium. In 6 cultures, the original explants were manually removed between days 15 and 25 after the epidermal outgrowth was grossly apparent and at least $3 \mathrm{~mm}$ in diameter as previously described $[16,17]$.

Control cultures included medium (560-mm Petri dishes), medium plus nonviable pigskin (5 60- $\mathrm{mm}$ Petri dishes), and primary (2 60- $\mathrm{mm}$ Petri dishes) and secondary cultures $(360-\mathrm{mm}$ Petri dishes) of human skin fibroblasts obtained from adult human breast skin planted in parallel with the keratinocytes cultures as previously described [22].

Collagenase Assays Conditioned medium was collected during routine medium changes and either tested immediately or frozen at $-70^{\circ} \mathrm{C}$ and tested within 2 weeks for collagenolytic activity. Collagenase assays were performed as described by Liotta and coworkers $[14,15]$ using $\left[{ }^{14} \mathrm{C}\right]$ proline-labeled pro-type IV collagen biosynthetically derived and isolated by acid extraction [23] from the Engelbreth-Holm-Swarm tumor or ${ }^{14} \mathrm{C}$-labeled type I collagen derived from guinea pig and labeled chemically by reductive alkylation [24]. The labeled collagens had a specific activity of approximately $10^{6} \mathrm{cpm} / \mathrm{mg}$. The conditioned medium from each culture was tested in triplicate. A positive control using $0.1 \%$ bacterial collagenase (Worthington) was performed in parallel in each experiment. Conditioned medium was obtained between days 6 and 55 of culture. A total of 32 outgrowth-producing keratinocyte cultures, 4 non-outgrowth-producing keratinocyte cultures, 5 fibroblast cultures, 5 medium alone controls, and 5 medium plus pigskin substrate controls were tested.

Enzyme solution (conditioned media or $0.1 \%$ bacterial collagenase $(400 \mu \mathrm{l})$ was placed in tubes with $400 \mu \mathrm{l}$ of $0.05 \mathrm{M}$ Tris$\mathrm{HCl}, 0.2 \mathrm{M} \mathrm{NaCl}, 10 \mathrm{mM} \mathrm{CaCl}_{2} \mathrm{pH} 7.6$ (collagenase buffer) in triplicate and activated by incubation with $100 \mu \mathrm{l}$ of $0.01 \%$ trypsin (an optimal concentration for both bacterial collagenase and conditioned medium-derived collagenase) at $37^{\circ} \mathrm{C}$ for $5 \mathrm{~min}$ at which time $100 \mu \mathrm{l}$ of $0.05 \%$ soybean trypsin inhibitor was added and the samples cooled to $4^{\circ} \mathrm{C}$ for $10 \mathrm{~min}$. Approximately $2000 \mathrm{cpm} / 50$ $\mu \mathrm{l}$ of $\left[{ }^{14} \mathrm{C}\right]$ proline-labeled collagen were added to each tube and incubated in a $30^{\circ} \mathrm{C}$ water bath for $5-7 \mathrm{~h}$. The samples were then cooled to $4^{\circ} \mathrm{C}$ for $20 \mathrm{~min}$. Twenty microliters of $0.5 \%$ bovine serum albumin and $70 \mu \mathrm{l}$ of a $10 \%$ trichloroacetatic acid (TCA), $0.5 \%$ tannic acid, and $2 \mathrm{mM} \mathrm{L-proline} \mathrm{in} \mathrm{water} \mathrm{solution} \mathrm{were}$ added to each sample and incubated for $90 \mathrm{~min}$ at $4^{\circ} \mathrm{C}$ at which time the samples were spun at $2000 \mathrm{rpm}$ for $10 \mathrm{~min}$. Six hundred microliters of supernate were then counted in a Beckman 7800 liquid scintillation counter.

In certain experiments designed to visualize type IV collagen digestion products, the collagenase assays were performed for 8 $\mathrm{h}$ at $25^{\circ} \mathrm{C}$ and the digestion mixture electrophoresed on a $5 \%$ sodium dodecyl sulfate-polyacrylamide slab gel under a $3 \%$ stacking gel and run at $30 \mathrm{~mA}$ per side as described by Laemmli [25]. In these experiments, the conditioned media alone or in the pres- ence of EDTA, N-ethylmaleimide (NEM), and phenylmethylsulfonyl fluoride (PMSF), or PMSF was incubated in the assay.

After the electrophoresis, the labeled gels were fixed in $50 \%$ trichloroacetic acid, and dried. Fluorography was then performed by exposing the dried gels to Kodak X-omat film [26]. The digestion products were then compared with type IV collagen substrate alone.

Assay for Endogenous Collagenase in the Substrate The porcine substrate (Genetic Laboratories) is obtained from the skin of domestic swine that has been washed with soap and water, thinly sliced to $35 / 1000$ th of an inch with a keratotome, equilibrated in phosphate-buffered saline, $\gamma$-irradiated with $3.5 \mathrm{mrad}$, and frozen and thawed from liquid nitrogen to $37^{\circ} \mathrm{C}$ for at least 5 cycles. However, to evaluate the possibility that the nonviable pigskin substrate could be a source of collagenase in the cultures, the pigskin substrate was analyzed for endogenous collagenase according to a modified method described by Ryan and Woessner [27]. Four $4 \times 4 \mathrm{~cm}$ squares of frozen substrate were pulverized into a fine powder and $10-\mathrm{mg}$ aliquots placed into glass test tubes on ice. The samples were washed twice in and equilibrated in 3 $\mathrm{ml}$ of ice-cold $0.15 \mathrm{M} \mathrm{NaCl}, 0.05 \mathrm{M}$ calcium acetate, $\mathrm{pH} 7.5$. Penicillin $(200 \mathrm{U} / \mathrm{ml})$ and $250 \mu \mathrm{g}$ of streptomycin were added to each tube. In addition to experimental samples and blanks containing $0.005 \mathrm{M}$ EDTA, positive controls were established by adding 100 units $(1 \times)$ and 200 units $(2 \times)$ of bacterial collagenase (Advance Biofactures, Form III, Lynbrook, New York) to duplicate samples. Trypsin $(600 \mu 1$ of $0.01 \%)$ was added to all the tubes, and the samples were incubated at $37^{\circ} \mathrm{C}$ for $5 \mathrm{~min}$. Soybean trypsin inhibitor $(750 \mu \mathrm{l}$ of $0.05 \%)$ was then added and the tubes cooled on ice for $30 \mathrm{~min}$. The tubes were then incubated for 24 $\mathrm{h}$ in a water bath of $37^{\circ} \mathrm{C}$ with gentle agitation. At the end of the incubation, the samples were placed on ice for $30 \mathrm{~min}$, centrifuged at $100,000 \mathrm{~g}$ for $1 \mathrm{~h}$, and the supernatant recovered, lyophilized, hydrolyzed in $6 \mathrm{~N} \mathrm{HCl}$ after $\mathrm{N}_{2}$ flushing and evacuation, and analyzed for proline and hydroxyproline content by a high-pressure liquid chromatography method of amino acid analysis [28].

\section{RESULTS}

Culture Morphology On gross inspection of the cultures, the leading edge of the epidermal outgrowth could be readily discerned as progressively enlarging clear zones developing around each explant (Fig 1). Of the 80 explant cultures initiated, 72 produced a visible outgrowth of at least $2 \mathrm{~mm}$ diameter after 15 days of culture. In 3 of the 6 cultures in which the original explants were removed between days 15 and 25, the outgrowths continued to expand indistinguishably from cultures with explants in place. In 3 cultures, removal of the explants delayed the outgrowth $\mathrm{mi}$ gration from at least 2 explants when compared with unperturbed cultures. In cultures $25-30$ days old, the $4 \times 4 \mathrm{~cm}$ pigskin substrate was $60-100 \%$ covered by the epithelial cell outgrowth.

Microscopic examination of the cultures showed that the dermal collagen was thin and degraded beneath the migratory cultured epithelium (Fig 2). This degradation was heralded by a lightening of its tinctorial properties when stained with hematoxylin and eosin along with a generalized thinning and fragmentation of the tissue (Fig 2). These changes in substrate thickness and staining properties occurred only beneath the cultured cells and were not seen in areas of the substrate that were not yet covered by the migratory epithelium (Fig 2) or in identical pieces of substrate placed alone in culture in parallel with the experimental cultures.

Collagenolytic Activity Conditioned medium from the cultures (both outgrowth- and non-outgrowth-producing), unconditioned medium alone, and unconditioned medium with pigskin substrate alone were examined for collagenolytic activity against collagen types I and IV. The epidermal outgrowth-producing cultures assayed (32 of 80 ) all had significant collagenolytic activity against collagen types I and IV in the range of approximately $40-60 \%$ of the bacterial collagenase control (Figs 3 and 4, Table 


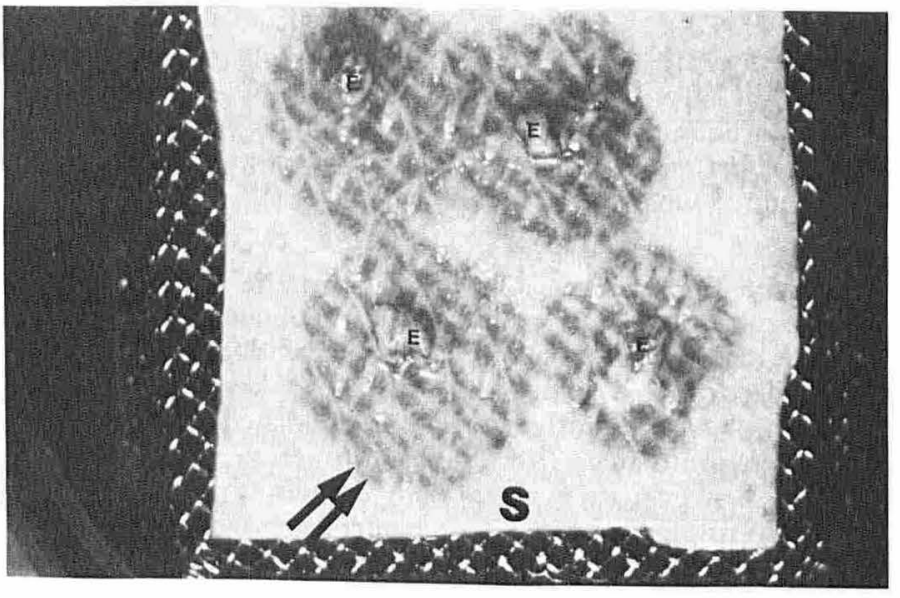

Figure 1. A photograph of the cultures showing 4 skin explants $(E)$ on nonviable inverted pigskin $(S)$ supported on a stainless steel platform in a Petri dish. As the epidermal cells migrate out from the explant and cross the substrate, clear zones develop around the explants. These clear zones correspond with the outgrowth cells. Arrows = leading edge of outgrowth cclls.
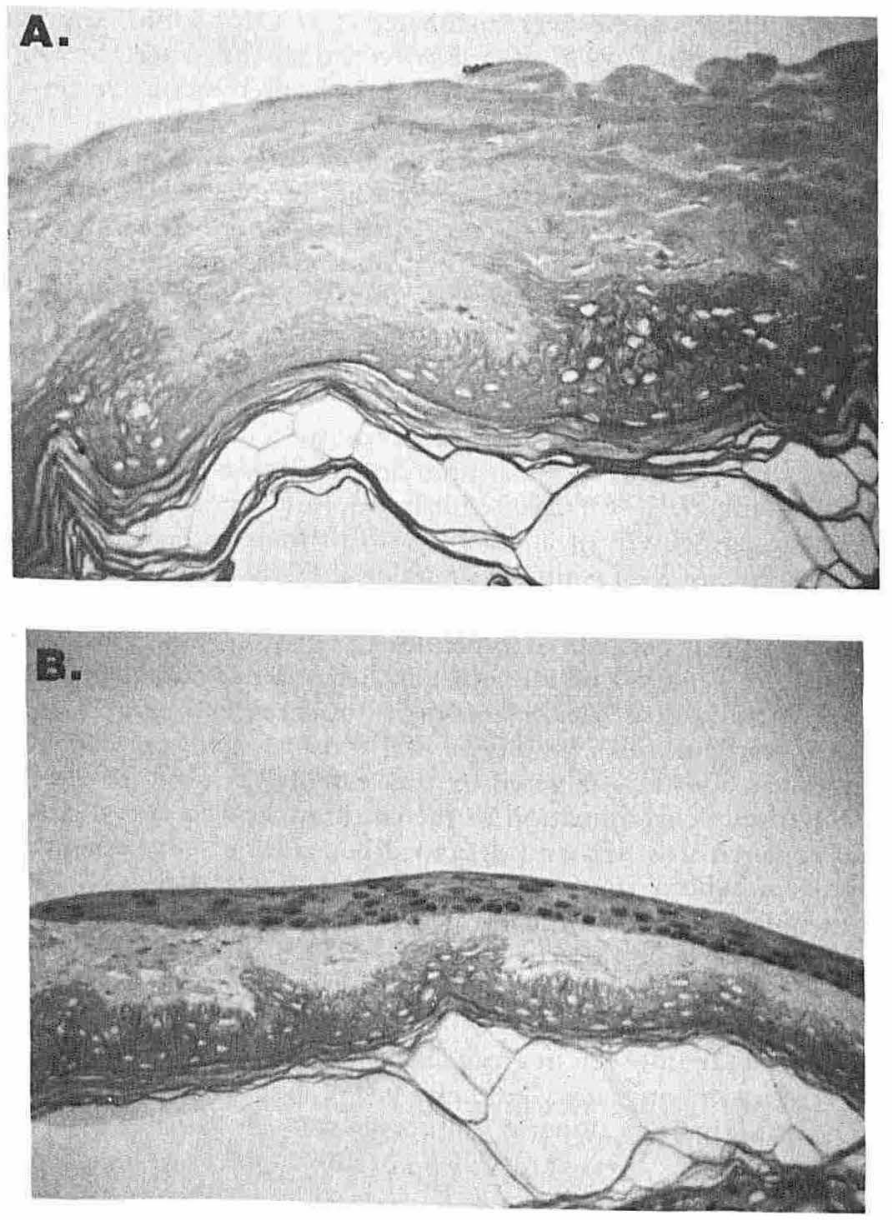

Figure 2. Photomicrographs $(A)$ and $(B)$, were taken at exactly the same magnification ( $\times 400$; courtesy of Dr. Robert A. Briggaman). Both are vertical sections of a 25 -day-old culture stained with H\&E but represent different areas of the same culture. $A$, An uncovered area of the dermal substrate. $B$, An area of the substrate covered with the epidermal cell outgrowth. Uncovered dermal substrate $(A)$ is much thicker than substrate covered by epidermal cells $(B)$.

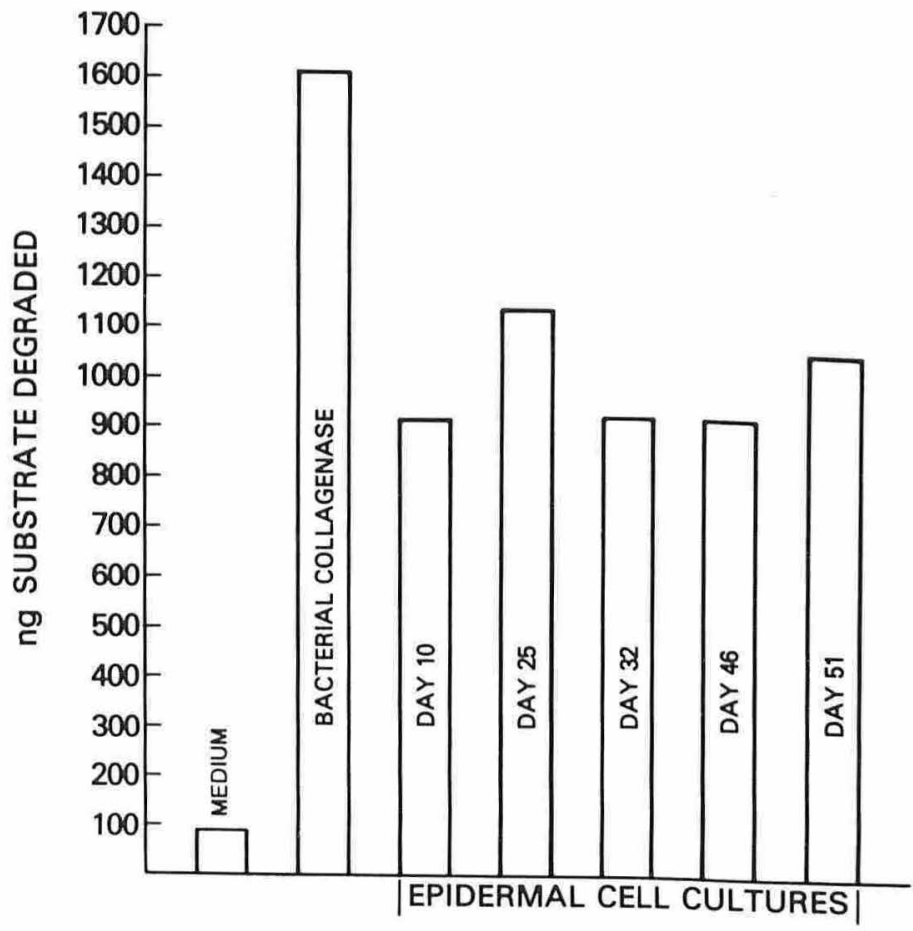

Figure 3. The capability of unconcentrated conditioned medium from epidermal cell cultures to degraded $\left[{ }^{14} \mathrm{C}\right]$ proline-labeled type I collagen at various days in culture compared with unconditioned medium and bacterial collagenase.

I). In accordance with the previous studies of Eisen [2,3], it should be noted that while there is definite type I collagenase activity in the epidermal cell conditioned medium, the activity (in the order of $1 \mu \mathrm{g}$ of collagen solubilized per $5 \mathrm{~h}$ ) is low compared with that usually found in fibroblast cultures. Unconditioned medium alone and unconditioned medium with pigskin substrate had collagenolytic activity less than $12 \%$ of the bacterial collagenase control (Fig 5). Medium from human skin fibroblast cultures had significant collagenolytic activity against type I collagen (35-45\% of the bacterial collagenase control) but very little activity against type IV collagen (less than $10 \%$ of bacterial collagenase control) as previously reported $[14,15]$ (Table I).

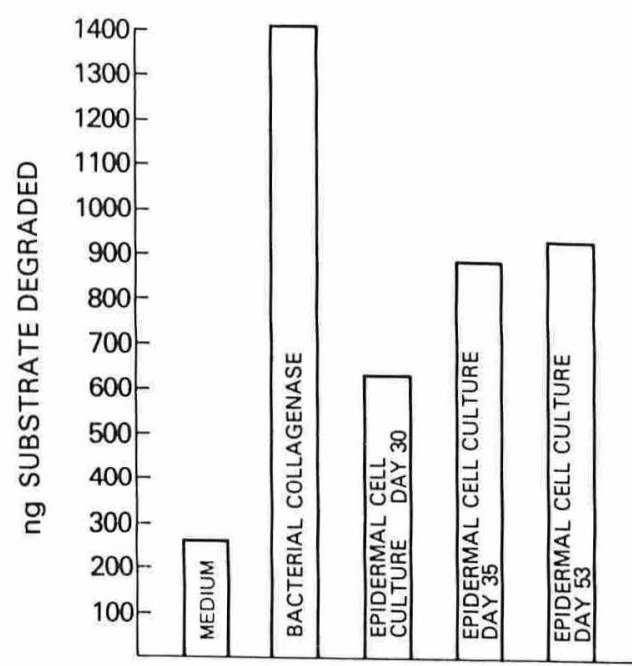

Figure 4. The capability of unconcentrated conditioned medium from epidermal cell cultures to degrade $\left[{ }^{14} \mathrm{C}\right]$ proline-labeled type IV collagen at various days in culture compared with unconditioned medium and
bacterial collagenase. 
Table I. Collagenase Assays

\begin{tabular}{lrr}
\hline & $\begin{array}{c}\text { Type IV } \\
\text { Activity }\end{array}$ & $\begin{array}{c}\text { Type I } \\
\text { Activity }\end{array}$ \\
\hline Migrating keratinocytes (32 cultures) & $58.5 \pm 8.3$ & $62.9 \pm 7.9$ \\
Medium alone (5 dishes) & $11.0 \pm 1.3$ & $6.0 \pm 1.4$ \\
Human skin fibroblasts (5 cultures) & $5.2 \pm 0.4$ & $34.7 \pm 3.1$ \\
\hline
\end{tabular}

The collagenase assays expressed in ng of substrate degraded and done in triplicate The collagenase assated here and the means expressed as a percentage of the bacterial collagenase positive controls that are included in each assay (sec Materials and Methods). positive controls that are included in each assay (sec Materials and Methods).

Four cultures (16 explants) with no visible outgrowths were tested and 3 had negligible collagenolytic activity against both collagen types equivalent to media controls $(5-8 \%$ of bacterial collagenase) and 1 had slightly elevated collagenase activity against type IV collagen ( $17 \%$ of bacterial collagenase control) but activity against type I collagen equivalent to that of medium controls.

The collagenase activity in the conditioned medium from outgrowth-producing cultures could be inhibited by incubating the medium in $0.010 \mathrm{M}$ EDTA prior to the collagenase assay. The incubation of $\left[{ }^{14} \mathrm{C}\right]$ proline labeled type IV collagen with conditioned medium from the keratinocyte cultures generated type IV collagen degradation products of 140 and $120 \mathrm{kD}$. This degradation of the type IV collagen was not inhibited by the addition of 2 serine protease inhibitors (0.010 M NEM or $0.002 \mathrm{M}$ PMSF) (Fig 6).

Substrate-Derived Collagenase Assay The raw data of the modified Ryan and Woessner [27] assay for endogenous collagenase in the pigskin substrate are presented in Table II. Exogenous bacterial collagenase added to the pigskin substrate released proline and hyroxyproline in a dose-dependent manner (tubes $1-4)$. In contrast, minimal release occurred in the experimental tubes without exogenous collagenase (tubes 5-8) in which only $0.4-0.2 \%$ of the total substrate weight was released. The proline/hydroxyproline ratios of the samples to which exogenous collagenase was added are near 1.5 or less (tubes 1-4), suggesting that the $1.5-5.5 \%$ of released substrate contains largely collagen. In contrast, in the samples without collagenase added the ratios are extremely high, which would suggest that the minimal amount of total substrate that was released $(0.415-0.236 \%)$ contains noncollagenous material.

\section{DISCUSSION}

In this study, we have shown that migrating keratinocytes produce a collagenase or collagenases that degrade both interstitial and basement membrane collagens. In addition to confirming the earlier work of Eisen [2,3], we have shown that migrating kerati-

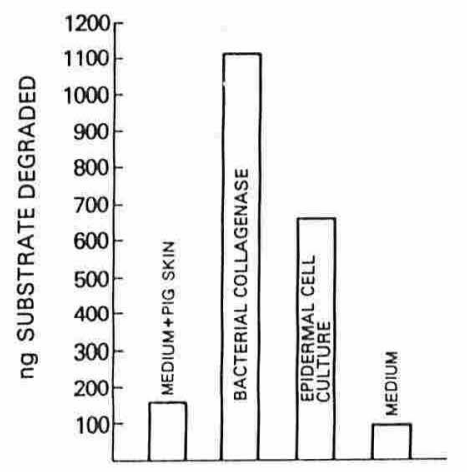

Figure 5. The capability of unconcentrated condition medium from 32day-old epidermal cell cultures to degrade $\left[{ }^{14} \mathrm{C}\right]$ proline-labeled type IV collagen compared to media alone and media plus pigskin (both negative controls) kept for the same length of time and handled identically to the cultures.

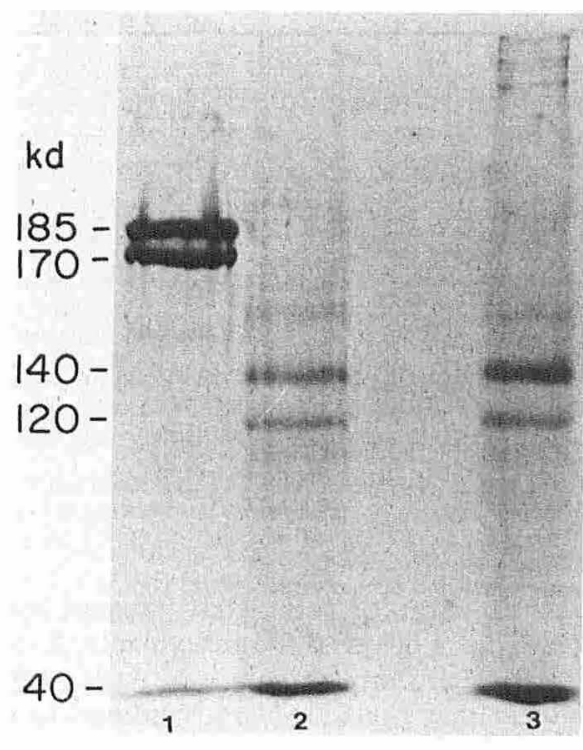

Figure 6. A fluorogram of a 5\% sodium dodecyl sulfate-polyacrylamide gel of $\left[{ }^{14} \mathrm{C}\right]$ proline-labeled type IV collagen that has been incubated with unconditioned medium (lane 1 ) or with condition medium from epidermal cell cultures (lanes 2 and 3) in the presence of either PMSF (lane 2) or NEM lane 3 .

nocytes in culture also produce a type IV collagenase. This is the first report of normal human keratinocytes producing a collagenase that degrades basement membrane collagen, an enzyme associated with malignant cells and their metastatic properties $[14,15]$.

One important issue that must be addressed in making such a claim is the possibility that fibroblasts contaminating the cultures could be responsible for the collagenase production. However, several observations argue against this possibility. First, the air-fluid interface does not support fibroblast growth and viability in these cultures while allowing the keratinocytes to proliferate and migrate across the dermal substrate [16-19]. Electron microscopic studies and leucine amino-peptidase staining of the cultures have shown that the outgrowth consists of stratified keratinocytes and does not contain fibroblasts $[18,19,21]$. Pure suspensions or cultures of skin fibroblasts placed on the dermal substrate and kept at an air-fluid interface quickly die and cannot be maintained [16]. Fibroblasts that could potentially "fall off' the substrate and subsequently grow on the submerged floor of the Petri dish are inhibited by using bacteriologic plastic Petri dishes (rather than those made from tissue culture plastic) and by changing Petri dishes with each change of medium (twice weekly).

However, it is still possible that fibroblasts within the $0.5 \times$ $0.5 \mathrm{~mm}$ explants could continue to live and metabolize but not divide. This situation would be somewhat analogous to the keratinocyte cultures of Rheinwald and Green [29] in which viable metabolizing but not dividing $3 \mathrm{~T} 3$ fibroblasts are cocultured with human keratinocytes. Johnson-Wint and Gross [30,31] have shown that keratinocyte-fibroblast interactions promote the collagenaseproducing capabilities of the fibroblasts. It could be argued that the collagenolytic activity in the medium of the cultures in this study is produced by metabolizing, nondividing fibroblasts confined to the explants and that their collagenase production is enhanced by the presence of keratinocytes. Against this possibility, however, is the fact that the conditioned medium has activity against type IV collagen. Earlier studies have shown that fibroblast cultures do not produce type IV collagenases $[8,15]$. Second, the fact that the morphologic degradation of the substrate occurs only beneath the epidermal outgrowth suggests that there is a high collagenase concentration at the interface between the migrating cultured cells and substrate. Third, the fact that a $4 \times 4$ 
Table II. Substrate-Derived Collagenase Assay

\begin{tabular}{|c|c|c|c|c|c|c|}
\hline \multirow[b]{2}{*}{ Tube } & \multirow{2}{*}{$\begin{array}{l}\text { Collagenase } \\
\text { Added }\end{array}$} & \multicolumn{2}{|c|}{$\begin{array}{c}\text { Proline and } \\
\text { Hydroxyproline } \\
\text { Released (nmol) }\end{array}$} & \multirow[b]{2}{*}{ P/OH-P Ratio } & \multirow{2}{*}{$\begin{array}{l}\text { Collagen Released } \\
\text { (mg) }\end{array}$} & \multirow{2}{*}{$\begin{array}{l}\text { \% Total } \\
\text { Substrate } \\
\text { Released }\end{array}$} \\
\hline & & $\mathrm{Pr}$ & $\mathrm{OH}-\mathrm{P}$ & & & \\
\hline 1 & $1 \times$ & 225 & 140 & 1.609 & 0.1526 & 1.52 \\
\hline 2 & $1 \times$ & 214 & 144 & 1.486 & 0.1571 & 1.57 \\
\hline 3 & $2 \times$ & 422 & 362 & 1.164 & 0.3959 & 3.96 \\
\hline 4 & $2 \times$ & 574 & 505 & 1.136 & 0.5520 & 5.50 \\
\hline 5 & 0 & 182 & 38 & 4.798 & 0.0415 & 0.415 \\
\hline 6 & 0 & 176 & 36 & 4.899 & 0.0393 & 0.393 \\
\hline 7 & 0 & 156 & 30 & 5.195 & 0.0328 & 0.328 \\
\hline 8 & 0 & 122 & 22 & 5.651 & 0.0236 & 0.236 \\
\hline
\end{tabular}

cm piece of substrate can be completely covered with epidermal cells generated from $40.5 \times 0.5 \mathrm{~mm}$ explants $(1$ square $\mathrm{mm}$ of explant on 1600 square $\mathrm{mm}$ of substrate $=1600$-fold increase) makes it unlikely that the fibroblasts confined to the explants could contribute greatly to the overall collagenase production in the cultures. Moreover, experiments in which the explant was removed between days 10 and 20 when the outgrowth was already established continued to exhibit collagenase activity. This would support the notion that fibroblasts within the explant are not contributing significantly to the collagenase levels in the cultures.

Although the substrate on which the keratinocytes migrate is rendered sterile and nonviable by $\gamma$-irradiation and multiple freezethaw cycles which are known to destroy collagenase activity [2], the possibility of a substrate-derived endogenous collagenase contributing to that found in the medium was excluded by assaying for collagenolytic activity present in the pigskin substrate. Bacterial collagenase added to the substrate shows positive release in a dose-dependent manner; however, these values are falsely low. This is because the dialysis step (even using $1500 \mathrm{kD}$ cut-off tubing) may allow for the loss of very small collagen fragments known to be generated with bacterial collagenase. The percent release for the pigskin substrates without added collagenase is less than $0.5 \%$ of the total collagen present, indicating nominal endogenous collagenolytic activity. Further, these values are not falsely low because in the experimental situations bacterial collagenase was not present. Any collagenase detected would be endogenous mammalian collagenase which would release large three-quarter/one-quarter collagen fragments that would not be lost by dialysis.

Using rabbit keratinocytes, Johnson-Wint and Gross [30,31] found no interstitial collagenase production when the cells were cultured alone. However, the keratinocytes were cultured on tissue culture plastic rather than collagen substrate. It is known that fibroblasts respond to collagen and altered cell shape by producing enhanced amounts of collagenase [32]. The difference in the species of the keratinocytes and the fact that our cultures were made on a dermal collagen substrate may explain the different results obtained by us and Johnson-Wint and Gross [31]. These investigators did not examine type IV collagenase production.

Perhaps equally important is the question of why migrating keratinocytes produce collagenases. Collagenolytic activity against interstitial collagen could be useful during wound healing in order to rid the wound site from debris as the keratinocytes migrate horizontally to cover the wound. It is more surprising that keratinocytes produce a collagenase against basement membrane collagen analogous to invasive metastatic cells. Like metastatic cells, these keratinocytes are highly migratory and are no longer in contact with their natural milieu, namely, molecules of the basement membrane zone. Rather, they are in contact with a variety of new connective tissue molecules (elastin, fibronectin, and collagens I and III) and experience the effect of being bathed in serum rather than plasma. Cultured cells attempt to reconstitute their matrix molecules for attachment to tissue culture plastic [33].
Keratinocytes preferentially attach to type IV collagen [34] and can synthesize a lamina densa. It is possible that for continued migration, keratinocytes must detach from newly formed "attachment" molecules, such as type IV collagen. Perhaps for continued cell locomotion (such as occurs during wound healing), keratinocytes synthesize type IV collagen, attach to it, and then release themselves from the matrix by the production of collagenases. The cell would move by a series of matrix synthesis, attachment, and release. In an in vivo wound healing animal model, Clark and colleagues [35] have observed that complete formation of type IV collagen in reconstituted basement membrane does not occur until the keratinocytes are in a nonmigratory state and the wound covered.

Although the studies reported here show that migratory adult human keratinocytes produce collagenases, it is unclear whether the signal for this process is a dermal matrix with a molecular composition quite different from basement membrane or whether induction of cell migration by soluble factors such as epibolin [36] could induce the cells to produce collagenase.

The authors are grateful to Ms. Sue Tyler and Ms. Donna Foushee for their technical assistance and to Dr. Howard Welgus for his excellent suggestions.

\section{REFERENCES}

1. Eisen AZ, Gross J: The role of epithelium and mesenchyme in the production of a collagenolytic enzyme and a hyaluronidase in the anuran tadpole. Dev Biol 12:408-412, 1965

2. Eisen AZ: Human skin collagenase: localization and distribution in normal human skin. J Invest Dermatol 52:442-448, 1969

3. Eisen AZ: Human skin collagenase: relationship to the pathogensis of epidermolysis bullosa dystrophica. J Invest Dermatol 52:449-453, 1969

4. Bauer EA, Stricklin GP, Jeffrey JJ, Eisen AZ: Collagenase production by human skin fibroblasts. Biochem Biophys Res Commun 64:232-240, 1975

5. Grillo HC, Gross J: Collagenolytic activity during mammalian wound repair. Dev Biol 15:300-317, 1967

6. Donoff RB: Wound healing: biochemical events and potential role of collagenase. J Oral Surg 28:356-363, 1970

7. Donoff RB, McLennan J, Grillo HC: Preparation and properties of collagenases from epithelium and mesenchyme of healing mammalian wounds. Biochim Biophys Acta 227:639-653, 1971

8. Welgus HG, Jeffrey JJ, Eisen AZ: The collagen substrate specificity of human skin fibroblast collagenase. J Biol Chem 256:9511-9515, 1981

9. Woolley DE, Glanville RW, Roberts DR, Evanson JM: Purification, characterization and inhibition of human skin collagenase. Biochem J 169:265-276, 1978

10. Horwitz AL, Hance AJ, Crystal RG: Granulocyte collagenase: selective digestion of type I relative to type III collagen. Proc Natl Acad Sci USA 74:897-901, 1978

11. McCrosky PA, Richards JF, Harris ED: Purification and character- 
ization of a collagenase extracted from rabbit tumors. Biochem J 152:131-142, 1975

12. Timpl R, Martin GR, Bruckner P: Structure of basement membrane collagen obtained from mouse tumor, Biochemistry and Pathology of Basement Membrane. Edited by L Robert. Basel, Karger, 1979, pp 120-129

13. Sage H: Collagens of basement membranes. J Invest Dermatol 79(suppl):51s-59s, 1982

14. Liotta L, Siegeto A, Gehron-Robey P, Martin GR: Preferential digestion of basement membrane collagen by an enzyme derived from a metastatic tumor. Proc Natl Acad Sci USA 76:2268-2272, 1979

15. Liotta LA, Tryggvason K, Garbisa S, Hart I, Foltz CM, Shafie S: Metastatic potential correlates with enzymatic degradation of basement membrane collagen. Nature 284:67-68, 1980

16. Freeman AE, Igel HJ, Herman BJ, Kleinfeld KL: Growth and characterization of human skin epithelial cell cultures. In Vitro 12:352-362, 1976

17. Milo GE, Ackerman GA, Noyes I: Growth and ultrastructural characterization of proliferating human keratinocytes in vitro without added extrensic factors. In Vitro 16:20-30, 1980

18. Woodley DT, Didierjean L, Regnier M, Saurat JH, Prunieras M: Bullous pemphigoid antigen synthesized in vitro by human epidermal cells. J Invest Dermatol 75:148-151, 1980

19. Didierjean L, Woodley DT, Regnier M, Prunieras M, Saurat JH: Skin explant culture expression of cytoplasmic differentiation antigens in outgrowth cells. J Invest Dermatol 76:38-41, 1981

20. Woodley DT, Regnier M, Prunieras M: In vitro basal lamina formation may require non-epidermal cell living substrate. Br J Dermatol 103:397-404, 1980

21. Regnier M, Prunieras M, Woodley DT: Growth and differentiation of adult human epidermal cells on dermal substrates. Front Matrix Biol 9:4-35, 1981

22. Kahaleh MB, Sherer GK, LeRoy EC: Endothelial injury in scleroderma. J Exp Med 149:1325-1335, 1979

23. Tryggvason K, Gehron-Robey P, Martin GR: Biosynthesis of type IV procollagens. Biochemistry 19:1284-1289, 1980

24. Paranjpe M, Engel L, Young N, Liotta L: Activation of human breast carcinoma collagenase through plasminogen activator. Life Sciences 26:1223-1231, 1980

25. Laemmli UK: Cleavage of structural proteins during the assembly of the head of bacteriophage T4. Nature 227:680-685, 1970

26. Bonner WM, Lasky RA: A film detection method for tritium-labeled proteins and nucleic acids in polyacrylamide gels. Eur J Biochem $46: 83-88,1974$

27. Ryan JN, Woessner JF: Mammalian collagenase: direct demonstration in homogenates of involuting rat uterus. Biochem Biophys Res Commun 44:144-149, 1971

28. Heinrikson RL, Meredith SC: Amino acid analysis by reverse-phase high performance liquid chromatography: precolumn derivitization with phenylisothiocyanate. Anal Biochem 136:65-74, 1984

29. Rheinwald JG, Green H: Scrial cultivation of strains of human cpidermal keratinocytes: the formation of keratinizing colonies from single cells. Cell 6:331-336, 1975

30. Johnson-Wint B: Regulation of stromal cell collagenase production in adult rabbit cornea: in vitro stimulation and inhibition by epithelial cell products. Proc Natl Acad Sci USA 77:5331-5335, 1980

31. Johnson-Wint B, Gross J: Regulation of connective tissue collagenase production: stimulators from adult and fetal epidermal cells. J Cell Biol 98:90-96, 1984

32. Aggeler J, Frisch SM, Werb Z: Changes in cell shape correlate with collagenase gene expression in rabbit synovial fibroblasts. J Cell Biol 98:1662-1671, 1984

33. Gospodarowicz D: The control of mammalian cell proliferation by growth factors, basement lamina, and lipoproteins. J Invest Dermatol 81(suppl):40s-50s, 1983

34. Murray JC, Stingl G, Kleinman HK, Martin GR, Katz SI: Epidermal cells adhere preferentially to type IV (basement membrane) collagen. J Cell Biol 80:197-202, 1979

35. Clark RAF, Lanigan JM, DellaPelle P, Manseau E, Dvorak HF, Colvin RB: Fibronectin and fibrin provide a provisional matrix for epidermal cell migration during wound reepithelialization. J Invest Dermatol 79:264-269, 1982

36. Stenn KS: Epibolin: a protein of human plasma that supports epithelial cell movement. Proc Natl Acad Sci USA 78:6907-6911, 1981 